\title{
A COMPARATIVE STUDY OF MENSTRUAL HYGIENE ISSUES BETWEEN PUBLIC AND PRIVATE SCHOOL GOING ADOLESCENT GIRLS IN KATHMANDU VALLEY
}

Ashok Pandey ${ }^{1}$, Narayan Bahadur Mahotra ${ }^{2 \dagger}$

${ }^{1}$ Research Officer, Nepal Health Research Council (NHRC), Ramshahpath, Kathmandu, Nepal,

${ }^{2}$ Assistant Professor, Department of Clinical Physiology, Maharajgunj Medical Campus, Institute of Medicine, Tribhuvan University, Nepal

†Corresponding author: email: narayanmahotra@gmail.com

\section{ABSTRACT}

Introduction: Menstruation is part a of the female reproductive cycle that starts when girls become sexually mature at the time of puberty. During menstrual period, woman bleeds from her uterus via the vagina. Menstruation is generally considered as unclean in our Nepali society. So, good hygienic practices such as the use of sanitary pads and adequate cleaning of the genital areas are essential during menstrual period.

Material and methods: The comparative study was carried out with adolescent girls studying in public and private schools in Kathmandu valley. A total of 100 adolescent girls, 50 from public school and another 50 from private schools were selected for the study and 25 from each group were taken for quantitative study as well. Two focus group discussions and five key-in-depth interviews were also done to identify the qualitative findings. Ethical approval was taken from NHRC. Quantitative data from the survey was analyzed using SPSS 16.0 software.

Results: The age of the respondents ranges from 11 to 18 years. The mean age at menarche was 12.37 years in both public and private school adolescent girls. There is a statistically significant difference on the overall score of practice during menstruation between public and private school going adolescent girls.

Conclusion: Private school adolescent girls were more knowledgeable and maintain menstrual hygiene better as compared to public school adolescent girls.

Keywords: Menstruation, Menstrual hygiene, Private school, Public School 


\section{INTRODUCTION}

Menstrual hygiene issues in a school going adolescent girls has been the topic of large number of studies in many countries. ${ }^{1}$ Several studies have been conducted all over the world to compare the various features of public and private schools. ${ }^{2}$ The researchers tried to make the sense of superiority of either by focusing on different measures of performance or the knowledge score. ${ }^{3}$ Menstruation is a natural phenomenon to the females. In each menstrual period, the bleeding from vagina lasts from 3 to 7 days depending upon the flow of blood. ${ }^{4}$ A cycle of 28 days is the menstrual period if the woman does not become pregnant at a time. ${ }^{5,4,6}$ Menarche starts at 10 to 14 years of age and menopause starts at around 45years but both the menarche and menopause varies with caste, race, ethnicity, socioeconomic status, and family status. Geographical conditions, racial factors, environmental influences, nutrition factors and physical activity can affect the age of menarche and menopause. ${ }^{7}$

During the adolescent period (ages between 10 to 19 years defined by WHO) dynamic transition takes place for biological development. ${ }^{8}$ Unhygienic and unhealthy menstrual practices increase the risk of reproductive tract infections and pelvic inflammatory diseases and other complications. ${ }^{9}$ During menstruation period, maintenance of good menstrual hygiene and special health care is needed. ${ }^{10}$ Negligence and poor management of menstruation can result in health problems such as infections of urinary system and potential risk of contracting blood-borne diseases such as hepatitis B infection. ${ }^{4}$ Menstruation can cause discomfort and high incidences of pain and also cause shifts in mood like depression.. ${ }^{4}$ In Nepal, there are cultural taboos which discourage girls from involving in teaching/learning activities during menstruation., ${ }^{5,71}$ So, female students elsewhere are very frequently absent in school during their menstrual period. Similarly, lack of school infrastructures like bathroom, toilet and availability of water are other important factors that make them hesitate from going to school . ${ }^{6}$ Abnormal physical conditions, particularly dysmenorrhea and excessive bleeding as well as mental stress during menstruation also affect the daily lives and routines of adolescent school girls. ${ }^{12,13,14}$

\section{MATERIALS AND METHODS}


A comparative study was carried out in adolescent girls studying in a private school (New Himalayan higher secondary school) and a public school (Ranidevi school) of Kathmandu valley for the duration of 6 weeks from $5^{\text {th }}$ June 2011 to $26^{\text {th }}$ July 2011. Both quantitative and qualitative methods were applied for the study. The total participants were 100 for the quantitative data and 26 for the qualitative data. A self- administered structured close-ended questionnaire, focus group discussion and key in-depth interview were used to collect the data. The questionnaire was prepared to collect relevant data from both the public and private school adolescent girls. The interview included topics related to awareness about menstruation, source of information regarding menstruation and hygienic practices during menstruation. The tools were first prepared in English language and then translated into Nepali language. Focus group discussion and semi-structured indepth interviews were recorded with a digital audio recording device. These areas include girl's toilet, school water source facilities, and absorbent material disposal areas.Quantitative data from the survey was analyzed using a statistical package of social science 16.0 software. Descriptive statistics were analyzed to show the socio-demographic characteristics as well as the distribution of knowledge and practices regarding menstrual hygiene and management. The major statistical methods used were frequency distribution, percentages, means, paired-sample T- Test. Qualitative data were gathered through in-depth interviews and two focus group discussions were conducted in order to gain an understanding of the patterns and practices around menstruation. Influencing factors to menstruation management and health seeking behavior were also explored. Data from focus group discussion and in-depth interview were transcribed verbatim from the audio record in Nepali language and translated later into English language. The data was then analyzed manually; based on recurrent themes and patterns. Informed verbal consent was taken from the respective head of school, respondents, and the participants before data collection. Pictures were taken and audio records were made with due verbal permission from the research respondents. Ethical approval was taken from Nepal health research council.

\section{RESULTS}

Socio-demographic characteristics of respondents: 
The study was carried out with adolescent girls studying in both public and private schools of Kathmandu valley. The age of the respondents ranges from 11 to 18 years. The mean age at menarche was 12.37 years in both groups of adolescent girls. Only 7 (7\%) of the adolescent girls were married. Most of the adolescent girls belonged to upper caste group (43\%) and Janajati (50\%). A Large majority of the respondents were Hindu by religion (67\%), followed by Buddhist (20\%). The occupations of the parents of the majority of the adolescent girls were agricultural/daily wages activities (father's - 53\%, mother's - 61\%). Geographically, 37 percent of the adolescent girls were from the inside Kathmandu valley, 37 percentof the adolescent girls were from the hilly regions outside Kathmandu valley (Dhading, Sindhupalchowk, Kavre, Ramechhap, Gorkha and other 10 districts) and remaining 26 percent of the respondents were from terai district.

\section{Knowledge and beliefs}

The study reveals that about 89 percent of the participants had heard about menstruation before their menarche. Among them, 86 percent adolescent girls were from private school and 92 percent were from public school. The finding of focus group discussion revealed a majority of the adolescent girls were not prepared in any way for their first menstruation. Adolescent girls described the onset of menarche as a shocking or fearful event that is remembered lifetime. (Table 1)

The findings of the FGD and key in-depth interview were also on the similar lines. One adolescent girl from Arghakhanchi shares her experiences about the "polluting touch" during the menstruation. I.e. do not see the sun and male members of the family, the practice of rituals in the form of restrictions on their movements and behavior, and cautions about behavior towards males.

The study revealed that 28 percent of the public school and 16 percent in private school were ever heard about sexually transmitted disease. From the key in-depth interview one of the respondents from Sindhupalchowk shares her experiences about the bleeding during menstruation,"she says the flow of impure blood materials outside our body. Menstruation is the natural process and in the time of menstruation, girls are prone to diseases like Hemorrhage, Anemia, over flow of blood with symptoms like Headache, Back pain, Backbone pain, Leg pain, Lethargy, dizziness”. (Table 
2) The study revealed that 34 percent of public school and 12 percent of private school adolescent girls says that normal flow of menstruation is up to 5-7 days. (Table 3)

70 percent of the public school girls and 72 percent of the private school girlswere feeling upset and tension during menarche. The focus group discussionshowed most of the girls expressed that "first menstruation is often traumatic and very negative experience, culturally girls of Brahmins, Khsetris, and Newari caste girls are put in seclusion they are not allowed to see the sun and male relatives (brothers and fathers").During menstruation period, boys might figure out about their movement and the facial expression during school hours. (Table 4)

\section{Misconception}

34 percent in public school and 12 percent in private school adolescent girlused to spray water if they mistakenly touch other people during menstruation. 5 percent in public school and 4 percent in private school adolescent girl used to take abath if mistakenly touch the people during menstruation period. (Table 5)

\section{Sources of knowledge about menstruation}

78 percent of the public school adolescent girls and 38 percent of the private school adolescent girls indicates main source of information about menstruation were parents. However, many respondents in focus group discussion expressed both male and female school teachers usually avoid teaching lessons related to reproductive health. Adolescent girls from Kavre exemplified it by quoting what her teacher had said: "This topic need not be taught, you can self-study at home. It's like knowing to eat food after hand washing”. (Table 6)

\section{Empirical Analysis and Results}

There is statistically significant difference $(\mathrm{P}=0.027)$ misconception about menstruation i.e. mistakenly touch other people and their practice to overcome the mistakes at $\alpha=0.05$ level of significance. (Table 7)

\section{Practices of seclusion, exclusion and absenteeism}


There is a statistically significant difference $(\mathrm{P}=0.038)$ on taking rest during the period of public and private school adolescent girl, at $\alpha=0.05$ level of significance. Similarly, there is statistically significant difference $(\mathrm{P}<0.002)$ on the overall score of practice during menstruation between public and private adolescent girls. (Table 8)

\section{Practice during menstruation}

There is a statistically significant difference $(\mathrm{P}=0.033,0.015)$ on use of pad during period, time of use of pad during the menstruation period of public and private schools, at $\alpha=0.05$ level of significance. (Table 9)

\section{Cleaning genitalia}

There is a statistically significant difference $(\mathrm{p}=0.022)$ on a technique used for cleaning genitalia during the menstruation period of public and private schools, at $\alpha=0.05$ level of significance. (Table 10)

\section{DISCUSSION}

The study shows that the mean age of menarche of adolescent girls was 13.30 years ( $S D \pm 1.127$ ). This data is comparable with kamarath $\mathrm{R}$. et $\mathrm{al}^{13}$ who reported the mean age of menarche of adolescent girls 13.98 years(S.D \pm 0.908 ). A study conducted in Rajasthan by Khanna A et al ${ }^{9}$ reported the mean age at menarche to be 13.2 years. Parents were the common source of information regarding menstruation for public school respondents. A similar finding was reported by other authors where the mother was the first informants ${ }^{13,14}$. However, information on menstruation given by mothers is often incomplete. 40 percent in private school adolescent girls mentioned that the textbooks were the main source of information.

The study showed that about 89 percent of the participants had heard about menstruation before their menarche. Among them, 86 percent of the adolescent girls were from private school and 92 percent of the adolescent girls were from public school. In focus group discussion, girls described the onset of menarche as a shocking or fearful event.The majority of the girls were not prepared in any way for their first menstruation. Fear and panic were the reaction observed in the study 
conducted by Pandey $\mathrm{A}^{5}$ and Kamath $\mathrm{R}$ et al. ${ }^{13}$ These negative feelings associated with menstruation could be because of participants not being psychologically prepared for attaining menarche which is an important milestone in their lives. Studies done on adolescent girls of Nepal were experienced upset and tension during their first period which reflect the cultural taboos in the society regarding menstruation. ${ }^{5}$ The unawareness of girls about menstruation might be the cause of embarrassment or apprehension at the onset of menstruation.

A study carried out by Datta A et al, ${ }^{15}$ shows that more than 80 percent of the participants had some restrictions imposed during menstruation. This is almost similar to our study where 34.0 percent in public school adolescent girls used to spray water if they mistakenly touch the people during menstruation. The study showed that there is statistically significant difference between public and private school girls regarding the misconception about menstruation such as spraying body with water by other people if they mistakenly touch them , taking rest during the period, using sanitary pad during bleeding period and timing of use of the pad during the menstruation .These finding was supported by Guya et $\mathrm{al}^{16}$ which showed that private school girls were found to perform better in terms of menstrual hygiene management than public school adolescent girls. Similarly, In our study private school adolescent girls seemed to be more knowledgeable than adolescent girls from public school. ${ }^{17}$

\section{CONCLUSION}

All females have to cope up with menstruation that is a natural process in women's life. From a physical and psychological point of view, menstruation period needs special care. Negligence in menstrual hygiene can result in biological disorders such as infections and excess menstrual bleeding leading to anemia with symptoms like headache, back pain, body pain, lethargy and dizziness. Unfortunately, awareness concerning this area of life is not highlighted due to sociocultural trends, norms, values, and customs of our society. In present age menstrual hygiene needs to be paid more attention during school adolescent girls.It has become necessary to analyze their relevant problems and prepare different strategies for a solution in school as well as at home. These solutions should be in accordance with social norms and traditions. Problems during menarche, effects of menstruation, proper use of hygiene products, hygiene practices during menarche and 
source of information regarding menstruation for girls have to be focused in the school curriculum. Although private school girls are more knowledgeable and maintain hygiene as compared to public school girls but menstrual knowledge and perceptions are poor in both school girls and practices often are not optimal to maintain proper hygiene in both group of girls. Menstrual hygiene promotion directly supports the gender equality, adolescent girl's empowerment and adolescent girl's performance. There should be narrowing the gap in public and private school education system with given priority to public school.

\section{REFERENCES}

1. Kumari G. A Study on Knowledge regarding Menstrual Hygiene among Adolescent School Girls. 2015;3(4):111-6.

2. Thakre SB, Thakre SS, Reddy M, Rathi N, Pathak K, Ughade S. Menstrual hygiene: Knowledge and practice among adolescent school girls of Saoner, Nagpur District. J Clin Diagnostic Res. 2011;5(5):1027-33.

3. Shabbir M, Wei S, Fu Y, Chong R. A Comparative Study of Public Versus Private Primary Schools, An Evidence From Azad Kashmir (Pakistan Occupied Kashmir). J Educ ... [Internet]. 2014;5(9):154-68. Available from: http://www.iiste.org/Journals/index.php/JEP/article/view/11879

4. Ade A, Patil R. Menstrual Hygiene and Practices of Rural Adolescent Girls of Raichur . Int J Biol Med Res. 2013;4(2):3014-7.

5. Pandey A. Challenges Experienced by Adolescent Girls while Menstruation in Kathmandu, Valley: A Qualitative Study. J Community Med Health Educ [Internet]. 2014;04(03):41-5. Available from: http://www.omicsonline.org/open-access/challenges-experienced-byadolescent-girls-while-menstruation-in-kathmandu-valley-a-qualitative-study-21610711.1000285.php?aid=25564

6. Wateraid. Is menstrual hygiene and management an issue for adolescent school girls ? A comparative study of four schools in different settings of Nepal. 2009;

7. Adhikari P. adolescent girls of Nepal. Knowl Pract regarding menstrual Hyg Rural Adolesc girls Nepal [Internet]. 2007;5(3):382-6. Available from: http://www.wsscc.org/sites/default/files/publications/knowledge-attitude-and-practiceregarding-menstrual-hygiene-in-rural-adolescent-girls-of-nepal-2007.pdf

8. Rana B, Prajapati A, Sonaliya KN, Shah V, Patel M, Solanki A. An Assessment of Menstrual Hygiene Practices amongst Adolescent Females at Kheda District of Gujarat State , India. Heal J. 2015;6(1):23-9. 
9. Sudeeshna R, Aparajita D. Determinants of Menstrual Hygiene among Adolescent Girls: A Multivariate Analysis. Natl J Community Med [Internet]. 2012;3(2):294-301. Available from: http://ucalgary.summon.serialssolutions.com/2.0.0/link/0/

10. Sreedhar M. Original article Practices of Menstrual hygiene among urban adolescent girls of Hyderabad. 2014;(December):478-86.

11. Jain K, Garg SK, Singh J V., Bhatnagar M, Chopra H, Bajpai SK. Reproductive health of adolescent girls in AN urban population of Meerut, Uttar Pradesh. Heal Popul Perspect Issues. 2009;32(4):204-9.

12. Patavegar BN, Kapilashrami MC, Rasheed N, Pathak R. Menstrual Hygiene among Adolescent School Girls : An In-Depth Cross- Sectional Study in an Urban Community. 2014;4(November):15-21.

13. Kamath R, Ghosh D, Lena A, Chandrasekaran V. A study on knowledge and practices regarding menstrual hygiene among rural and urban adolescent girls in Udupi Taluk , Manipal , India. Glob J Med Public Heal. 2013;3(1):1-9.

14. Jimenez E, Lockheed ME, Cox D, Luna E, Paqueo V, de Vera ML, et al. Public and private secondary education in developing countries [Internet]. 1995. Available from: http://www.worldbank.icebox.ingenta.com/content/wb/997

15. Education NH, Centre C. Further analysis of 2011 nepal demographic and health survey on tobacco data. 2013;(July).

16. Guya E, Mayo AW, Kimwaga R. Menstrual Hygiene Management in Secondary schools in Tanzania. Ijst. 2014;3(1):27-40.

17. Jamra $\mathrm{V}$ et. al.A comparative study of basic health services provided in government and private schools of Bhopal city. 2014;5(1):131-4. 
Tables and legends to illustrations

Table 1: Menstruation

\begin{tabular}{lcccc}
\hline Menstruation & \multicolumn{2}{c}{ Public school } & \multicolumn{2}{c}{ Private school } \\
\cline { 2 - 5 } & $\mathrm{N}$ & $\%$ & $\mathrm{~N}$ & $\%$ \\
\hline Physiological & 44 & $88.0 \%$ & 38 & $76.0 \%$ \\
\hline Pathological & 4 & $8.0 \%$ & 8 & $16.0 \%$ \\
\hline Hormone & 1 & $2.0 \%$ & 4 & $12.0 \%$ \\
\hline Curse & 1 & $2.0 \%$ & - & - \\
\hline Total & 50 & $100 \%$ & 50 & $100 \%$ \\
\end{tabular}

Table 2: Disease associated with menstruation

\begin{tabular}{cccccc} 
Heard about & sexually & transmitted & \multicolumn{2}{c}{ Public school } & \multicolumn{2}{c}{ Private school } \\
\cline { 2 - 6 } Infections (STIs) & & $\mathrm{N}$ & $\%$ & $\mathrm{~N}$ & $\%$ \\
\hline No & 14 & $28.0 \%$ & 8 & $16.0 \%$ \\
Yes & 36 & $72.0 \%$ & 42 & $84.0 \%$ \\
\hline Total & 50 & $100.0 \%$ & 50 & $100.0 \%$ \\
\hline
\end{tabular}

Table 3: Normal flow of Menstruation

\begin{tabular}{|lcccc}
\hline Flow of menstruation & \multicolumn{2}{c}{ Public school } & \multicolumn{2}{c}{ Private school } \\
\cline { 2 - 5 } & $\mathrm{N}$ & $\%$ & $\mathrm{~N}$ & $\%$ \\
\hline 3-5 days & 33 & $66.0 \%$ & 44 & $88.0 \%$ \\
\hline 5-7 days & 17 & $34.0 \%$ & 6 & $12.0 \%$ \\
\hline Total & 50 & $100.0 \%$ & 50 & $100.0 \%$ \\
\hline
\end{tabular}


Table 4: Feeling during menarche

\begin{tabular}{lcccc}
\hline Feeling during menarche & \multicolumn{2}{c}{ Public school } & \multicolumn{2}{c}{ Private school } \\
\cline { 2 - 4 } & $\mathrm{N}$ & $\%$ & $\mathrm{~N}$ & $\%$ \\
Normal & 15 & $30.0 \%$ & 14 & $28.0 \%$ \\
Upset and Tension & 35 & $70.0 \%$ & 36 & $72.0 \%$ \\
Total & 50 & $100.0 \%$ & 50 & $100.0 \%$ \\
\hline
\end{tabular}

Table 5: Misconception about the menstruation

\begin{tabular}{lcccc}
\hline Touch other people during period & \multicolumn{2}{c}{ Public school } & \multicolumn{2}{c}{ Private school } \\
\cline { 2 - 5 } & $\mathrm{N}$ & $\%$ & $\mathrm{~N}$ & $\%$ \\
\hline Spray water & 17 & $34.0 \%$ & 6 & $12.0 \%$ \\
\hline Nothing & 28 & $56.0 \%$ & 40 & $80.0 \%$ \\
\hline Bath & 5 & $10.0 \%$ & 4 & $8.0 \%$ \\
\hline Total & 50 & $100.0 \%$ & 50 & $100.0 \%$ \\
\hline
\end{tabular}

Table 6: Source of knowledge about menstruation

\begin{tabular}{lcccc}
\hline $\begin{array}{l}\text { Taught during menstruation for } \\
\text { menstrual hygiene }\end{array}$ & \multicolumn{2}{c}{ Public school } & \multicolumn{2}{c}{ Private school } \\
\cline { 2 - 4 } & $\mathrm{N}$ & $\%$ & $\mathrm{~N}$ & $\%$ \\
Parents & 39 & $78.0 \%$ & 32 & $64.0 \%$ \\
Friends & 5 & $10.0 \%$ & 5 & $10.0 \%$ \\
Text book & 3 & $6.0 \%$ & 13 & $26.0 \%$ \\
None & 3 & $6.0 \%$ & - & - \\
Total & 50 & $100.0 \%$ & 50 & $100.0 \%$
\end{tabular}

Appropriate sources for menstruation and menstrual hygiene study
Text book
6
$12.0 \%$
7
$14.0 \%$ 
Original Article

$\begin{array}{lcccc}\text { Teacher } & 5 & 10.0 \% & 12 & 24.0 \% \\ \text { Parents } & 19 & 38.0 \% & 12 & 24.0 \% \\ \text { All of above } & 20 & 40.0 \% & 19 & 38.0 \% \\ \text { Total } & 50 & 100.0 \% & 50 & 100.0 \%\end{array}$

Table 7: Misconception about menstruation

\begin{tabular}{|c|c|c|c|c|c|c|c|c|c|}
\hline \multirow[t]{2}{*}{ Misconception } & \multicolumn{2}{|c|}{$\mathbf{N}$} & \multicolumn{2}{|c|}{ Mean } & \multicolumn{2}{|c|}{$\begin{array}{l}\text { Standard } \\
\text { deviation }\end{array}$} & \multicolumn{3}{|c|}{ T test } \\
\hline & Public & Private & Public & Private & Public & Private & $\overline{\mathrm{DF}}$ & T value & Sig. \\
\hline $\begin{array}{l}\text { Overcoming } \\
\text { practices }\end{array}$ & 1.76 & 2.00 & 50 & 50 & 0.625 & 0.495 & 49 & 2.281 & $\begin{array}{c}0.02 \\
7\end{array}$ \\
\hline
\end{tabular}

Table 8: Practices of seclusion, exclusion and absenteeism

\begin{tabular}{|l|l|c|c|c|c|c|c|c|c|c|}
\hline $\begin{array}{l}\text { S. } \\
\text { N }\end{array}$ & $\begin{array}{l}\text { Practice during } \\
\text { menstruation }\end{array}$ & \multicolumn{2}{|c|}{ N } & \multicolumn{2}{|c|}{ Mean } & \multicolumn{2}{c|}{$\begin{array}{l}\text { Standard } \\
\text { deviation }\end{array}$} & \multicolumn{3}{c|}{ T test } \\
\cline { 2 - 11 } & Public & Private & Public & Private & Public & Private & DF & \multicolumn{1}{|c|}{$\begin{array}{l}\text { S- } \\
\text { value }\end{array}$} \\
\hline 1 & $\begin{array}{l}\text { Goes to School } \\
\text { during Period }\end{array}$ & 50 & 50 & 0.90 & 0.92 & 0.274 & 0.303 & 49 & 0.330 & 0.743 \\
\hline 2 & $\begin{array}{l}\text { Cook food during } \\
\text { Period }\end{array}$ & 50 & 50 & 0.66 & 0.52 & 0.479 & 0.505 & 49 & 1.358 & 0.181 \\
\hline 3 & $\begin{array}{l}\text { Sleep in usual house } \\
\text { during first period }\end{array}$ & 50 & 50 & 0.68 & 0.76 & 0.471 & 0.431 & 49 & 0.781 & 0.438 \\
\hline 4 & $\begin{array}{l}\text { Clean genitalia for } \\
\text { menstrual purpose }\end{array}$ & 50 & 50 & 0.94 & 0.92 & 0.240 & 0.274 & 49 & 0.375 & 0.709 \\
\hline 5 & $\begin{array}{l}\text { Take rest during } \\
\text { period }\end{array}$ & 50 & 50 & 0.90 & 0.72 & 0.303 & 0.454 & 49 & 2.137 & 0.038 \\
\hline 6 & Overall score & 50 & 50 & 8.840 & 3.9800 & 1.5433 & .97917 & 49 & 17.54 & 0.000 \\
& & & & 0 & & 9 & & & 4 & \\
\hline
\end{tabular}


Original Article

Table 9: Practice during menstruation

\begin{tabular}{|l|l|l|l|l|l|l|l|l|l|l|}
\hline S.N & Practices & N & \multicolumn{2}{|l|}{ Mean } & \multicolumn{2}{l|}{$\begin{array}{l}\text { Standard } \\
\text { deviation }\end{array}$} \\
\cline { 3 - 11 } & Public & Private & Public & Private & Public & Private & DF & $\begin{array}{l}\text { t- } \\
\text { value }\end{array}$ & Sig. \\
\hline 1 & $\begin{array}{l}\text { Use pad during } \\
\text { period }\end{array}$ & 50 & 50 & 0.82 & 0.96 & 0.388 & 0.198 & 49 & 2.189 & 0.033 \\
\hline 2 & $\begin{array}{l}\text { Times of use } \\
\text { pad }\end{array}$ & 50 & 50 & 2.00 & 2.36 & 0.700 & 0.598 & 49 & 2.532 & 0.015 \\
\hline 3 & Reuse pad & 50 & 50 & 0.18 & 0.06 & 0.388 & 0.240 & 49 & 1.769 & 0.083 \\
\hline 4 & $\begin{array}{l}\text { Materials used } \\
\text { in pad }\end{array}$ & 50 & 50 & 1.86 & 1.86 & 0.495 & 0.351 & 49 & 0.000 & 1.000 \\
\hline 5 & Share pad & 50 & 50 & 0.06 & 0.06 & 0.240 & 0.240 & 49 & 0.000 & 1.000 \\
\hline
\end{tabular}

Table 10: Cleaning genitalia

\begin{tabular}{|l|l|c|c|c|c|c|c|c|c|c|}
\hline \multirow{2}{*}{$\begin{array}{l}\text { S. } \\
\text { N }\end{array}$} & Clean genitalia & \multicolumn{2}{|c|}{ N } & \multicolumn{2}{c|}{ Mean } & \multicolumn{2}{c|}{$\begin{array}{l}\text { Standard } \\
\text { deviation }\end{array}$} & \multicolumn{3}{c|}{ T test } \\
\cline { 3 - 11 } & Public & Private & Public & Private & Public & Private & DF & $\begin{array}{c}\text { t- } \\
\text { value }\end{array}$ & Sig. \\
\hline 1 & $\begin{array}{l}\text { Clean genitalia for } \\
\text { menstrual purpose }\end{array}$ & 50 & 50 & 0.92 & 0.94 & 0.274 & 0.240 & 49 & -.375 & 0.709 \\
\hline 2 & $\begin{array}{l}\text { Technique used for } \\
\text { cleaning genitalia }\end{array}$ & 50 & 50 & 1.98 & 1.54 & 0.915 & 0.788 & 49 & 2.372 & 0.022 \\
\hline 3 & $\begin{array}{l}\text { Using substance for } \\
\text { cleaning genitalia }\end{array}$ & 50 & 50 & 1.38 & 1.22 & 0.490 & 0.418 & 49 & 1.661 & 0.103 \\
\hline
\end{tabular}

